\title{
Interactive Use of Barbels by Spotted Goatfish Pseudupeneus maculatus (Bloch, 1793) on the Reef of Bonaire, Lesser Antilles
}

\author{
Genady Filkovsky* and Joseph T. Springer \\ Biology Department, University of Nebraska-Kearney, 905 W 25 $5^{\text {th }}$ Street, Kearney, Nebraska 68849-1140, USA
}

\begin{abstract}
New behavior by spotted goatfish Pseudupeneus maculatus (Bloch, 1793) was observed. Spotted goatfish interacted by wriggling, touching, and twisting each other's barbels. Detailed observations suggest agonistic encounters of two males as interpretation of this behavior. This observed use of barbels by goatfish differs from their common uses in feeding, and from their previously noted use in courtship. This new behavior also suggests an interpretation for the latter.
\end{abstract}

Keywords: Mullidae, behavior, interaction, male competition.

\section{INTRODUCTION}

A distinct feature of goatfishes (Family Mullidae) is a pair of highly developed hyoid barbels [1]. These are long, powerful structures with muscles, cartilaginous skeleton, and sensory organs [2]. When not in use, the barbels are folded back inside grooves under the chin and gill covers; when in use, the barbels can be lowered as well as turned all the way forward, or rapidly and independently bent [1].

The goatfish barbels are considered to be chemosensory and tactile organs mainly used for feeding [2]. All goatfishes are believed to use barbels in feeding by lowering them to the sea bottom to sense hidden prey [1]. Goatfishes also use their barbels for feeding in various ways beyond sensory probing. Examples include disturbing and excavating sand or mud to reach hiding prey, or frightening, pushing, and pulling prey from holes and crevices $[1,3]$. One use of barbels not related to feeding is seen in male goatfish of the genus Parupeneus in the Pacific, rapidly wriggling their barbels during courtship [4].

A behavioral repertoire of the spotted goatfish Pseudupeneus maculatus (Bloch, 1793) was recorded for a study of animal behavior. A novel use of barbels by spotted goatfish was detected during data collection and subsequent analysis of the recordings. Unlike previously reported uses, in these observations barbels were used mutually and simultaneously by interacting $P$. maculatus.

\section{OBSERVATION SITES AND METHODS}

Three observations of the novel behavior occurred on the leeward coral reef of Bonaire, Lesser Antilles, in the vicinity with geographic coordinates $12^{\circ} 09^{\prime} 35^{\prime \prime} \mathrm{N}, 68^{\circ} 16^{\prime} 56^{\prime \prime} \mathrm{W}$. Bonaire National Marine Park was the location of data collection. Data were collected by videotaping spotted goatfish while following them using SCUBA gear. Specimens were not collected because of the restrictions of Bonaire National Marine Park.

*Address correspondence to this author at the Biology Department, University of Nebraska-Kearney, $905 \mathrm{~W} 25^{\text {th }}$ Street, Kearney, Nebraska 68849-1140, USA; Tel: +599-717-4593; Fax: +599-717-4593; E-mail: lagoenhill20@yahoo.com
The behavior was first observed at 16:00 on 5 March 2009 in $5 \mathrm{~m}$ of water about $30 \mathrm{~m}$ from shore and $10 \mathrm{~m}$ in front of the reef drop-off. This area was a reef flat covered with sand and coral rubble. The water temperature was $26^{\circ} \mathrm{C}$, visibility $15 \mathrm{~m}$; conditions were calm and clear. The behavior was already in progress at the start of the video recording and continued afterwards. The observation lasted 20 minutes.

The second observation occurred at 17:00 on 9 July 2009 about $30 \mathrm{~m}$ to the north in an area similar to the first. The water temperature was $28^{\circ} \mathrm{C}$, visibility $10 \mathrm{~m}$; conditions were calm and clear. This was a 3 minute video recording.

The third time the behavior was observed at 16:00 on 3 September 2009 approximately $50 \mathrm{~m}$ farther north on top of the reef drop-off ( $8 \mathrm{~m}$ deep) with rocky bottom and live hard corals. The water temperature was $28^{\circ} \mathrm{C}$, visibility $20 \mathrm{~m}$; conditions were calm and clear. This observation lasted about half a minute and was not video recorded.

\section{RESULTS}

During the first observation, two adult $P$. maculatus (each approximately $20 \mathrm{~cm}$ in total length) repeated 72 times the following behavioral pattern while staying $0.5 \mathrm{~m}-2 \mathrm{~m}$ above the bottom. They (1) swam toward each other, (2) stopped while facing each other, with approximately $5 \mathrm{~cm}$ between their snouts, (3) vigorously wriggled barbels in a fencing-like manner for about $1 \mathrm{sec}$, (4) separated, (5) turned around, (6) swam a few meters away from each other, (7) turned around to face each other, and then continued again starting with step 1 . Each such bout took $17 \pm 6 \mathrm{sec}$ (mean \pm SD). A few times after swimming away from each other (step 6) one individual turned around (step 7) while the other was still swimming. The former then followed the latter until it turned around.

Approaching each other from a distance (step 1) both $P$. maculatus had their barbels tucked under the chin. Coming closer, they simultaneously moved the barbels forward. In 57 of the 72 bouts, after wriggling their barbels (step 3), they simply both retreated (step 4) (Fig. 1A). In 15 of the 72 bouts, their behavior after wriggling the barbels was 

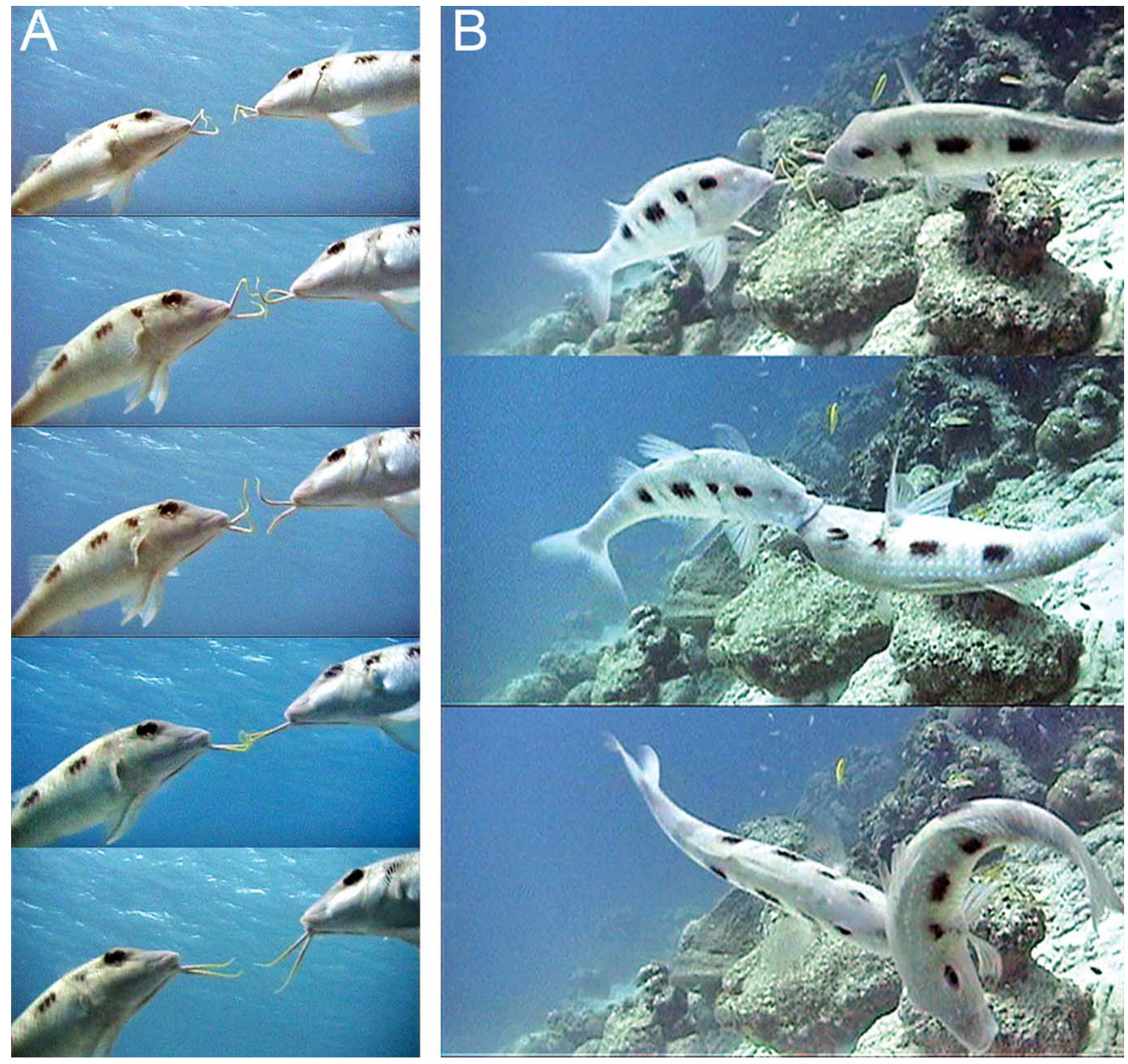

Fig. (1). Pseudupeneus maculatus interact using barbels: (A, top to bottom) approach, twist, wriggle, touch, and separate; (B, top to bottom) wriggle, "rush", and dart.

different. The fish "rushed" each other by closing the gap between them, pushing and twisting around each other; one closed its mouth over the other's snout in two such rushes (Fig. 1B). Each of these rushes lasted less than half a second, being observed only by replaying the video recording in slow motion. These rushes occurred irregularly, two or three times in a row, or after as many as 12 wriggling bouts without a rush.

Two adult $P$. maculatus slowly swam together in the second observation, followed each other, circled, and then rested on the bottom. They turned and swam toward each other and briefly wriggled barbels 4 times. Finally they disengaged, one staying, the other swimming away. A third, smaller P. maculatus (approximately $15 \mathrm{~cm}$ in total length) was noted in the vicinity during this observation.

In the third observation, one $P$. maculatus was on the bottom while another circled and approached it twice. On each approach they wriggled barbels. During a third approach a smaller $P$. maculatus swam by them toward the reef drop-off. The first two immediately followed it, and then all three proceeded down the reef slope.

\section{DISCUSSION}

Considering general patterns of reef fish behaviors, the paired behavior reported here could be interpreted either as 
spawning or as an agonistic encounter between two males. $P$. maculatus pair spawning consists of a female rising in the water column, a male coming alongside her, and then both quickly swimming $2 \mathrm{~m}-3 \mathrm{~m}$ at about 45 degrees up, spawning, breaking off, and returning to the bottom [5]. The behavior reported here was different. No eggs and milt were seen, while they are easily observable in $P$. maculatus spawning [6]. The fish were similar in size and shape while male $P$. maculatus differ from females $[7,8]$. Consequently, this new behavior likely was an agonistic behavior between two males. The third P. maculatus in the vicinity during the last two observations presumably were females.

The common element in all three observations was mutual wriggling of barbels while other details varied. This use of barbels by goatfish differed from previously described (1) because it constituted a new function of barbels that was not concerned with feeding, and (2) because it was interactive. The interactive wriggling of barbels could constitute a competitive comparison of barbels by two males, similar to male insects comparing their antennas, and to male deer comparing their antlers.

This newly observed use of barbels could provide a framework to explain wriggling barbels by courting male goatfish of the genus Parupeneus in the Pacific [4]. Perhaps by wriggling barbels in courtship, the males advertise their ability to compete with other males. It is significant in this light that the two genera in which the barbel wriggling has been thus far observed, Parupeneus and Pseudupeneus, are closely related to each other. Differences from other Mullidae are more radical than the differences between Parupeneus and Pseudupeneus [1]. The behavioral peculiarity of barbel wriggling that is common to these two genera and that was not observed in other Mullidae, adds to these relations. It is not known at this time whether Parupeneus also wriggle barbels in interactions, or whether Pseudupeneus also wriggle them in courtship. More observations of barbel wriggling by goatfish of various taxa and in various locations are needed to fully understand this behavior and its significance.

\section{REFERENCES}

[1] Gosline WA. Structure, function, and ecology in the goatfishes (Family Mullidae). Pacific Sci 1984; 38: 312-23.

[2] Fox H. Barbels and barbel-like tentacular structures in submammalian vertebrates: a review. Hydrobiologia 1999; 403: 15393.

[3] Krajewski JP, Bonaldo RM, Sazima C, Sazima I. Foraging activity and behavior of two goatfish species (Perciformes: Mullidae) at Fernando de Noronha Archipelago, tropical West Atlantic. Environ Biol Fishes 2006; 18: 303-8.

[4] Randall JE, Allen GR, Steene RC. Fishes of the Great Barrier Reef and Coral Sea. Revised and expanded ed. Honolulu: University of Hawaii Press 1997.

[5] Colin PL, Clavijo IE. Spawning activity of fishes producing pelagic eggs on a shelf edge coral reef, Southwestern Puerto Rico. Bull Mar Sci 1988; 43: 249-79.

[6] Colin PL, Clavijo IE. Mass spawning by the spotted goatfish, Pseudupeneus maculatus (Bloch) (Pisces: Mullidae). Bull Mar Sci 1978; 28: 780-2.

[7] Caldwell MC. Development and distribution of larval and juvenile fishes of the family Mullidae of the Western North Atlantic. Fishery Bull Fish Wildl Serv 1962; 62: 403-57.

[8] Munro JL. Aspects of the biology and ecology of Caribbean reef fishes: Mullidae (goat-fishes). J Fish Biol 1976; 9: 79-97.

(C) Filkovsky and Springer; Licensee Bentham Open.

This is an open access article licensed under the terms of the Creative Commons Attribution Non-Commercial License (http://creativecommons.org/licenses/by$\mathrm{nc} / 3.0 /$ ), which permits unrestricted, non-commercial use, distribution and reproduction in any medium, provided the work is properly cited. 